\title{
Interdisciplinary, Collaborative International Service Learning: Developing Engineering Students as Global Citizens
}

\author{
Anthony D. Songer \\ Professor, College of Engineering, \\ Department of Construction Management \\ Boise State University \\ Boise, ID 83725
}

\author{
Karen R. Breitkreuz \\ Assistant Professor, College of Health Sciences, \\ School of Nursing \\ Boise State University \\ Boise, ID 83725
}

\begin{abstract}
Recent calls to reform engineering education place emphasis on applied math and science within the broader context of globalization, economics, the environment, and society. This broad and complex challenge necessitates the investigation of new interdisciplinary education approaches for engineering education. This paper presents a formal approach for developing engineering students as global citizens. The 360 Degree Model for Educating Socially Responsible Global Citizens (360 Global Ed model) presented herein includes a framework for foundational theory, educational environment, academic coursework, and outcomes. At the core of the emerging model is an international service learning experience called the Village Network. The Village Network provides an interdisciplinary educational program that combines classroom learning with authentic international field experiences. The program responds to the demands for integrating technical and social domains in a multi-disciplined, globally sensitive paradigm. The multidisciplined team approached addresses both internal outcomes of self mastery and motivation that propel individuals to engage as socially responsible global citizens and external outcomes of technical and social knowledge and skills to include sustainability, teaming, and leadership. This paper establishes the need for a global imperative for engineering education and provides a background on globalization, social responsibility and service learning. It describes the $\mathbf{3 6 0}$ degree model for educating socially responsible global citizens and provides pilot assessment results through a mixed methods approach.
\end{abstract}

Index Terms - Collaboration, Global Responsibility, Global Citizenship, Leadership, Multidisciplined Teams, Service-Learning, Social Responsibility

\section{INTRODUCTION}

Public and private organizations continue to emphasize the importance of globalization. Global competitiveness, resulting from an increasingly inter-connected global society and economy creates an imperative for graduates of U.S. higher education to become globally competent and socially responsible. ${ }^{1,2,3,4,5,6}$

The frontiers of globalization provide tremendous opportunities and create complex challenges for the Science, Technology, Engineering, and Math (STEM) community. While STEM disciplines provide the foundation for solving many of the world's pressing issues, the shortage of STEM majors threatens U.S. competitiveness and leadership in global markets. ${ }^{7,8}$ 
Former NSF Director Subra Suresh underscores the need to consider a global emphasis in his statement, "The $21^{\text {st }}$ century is the century of science and technology and is not for people who are in the STEM enterprise, but for the average citizens of the world. They have to be science savvy, they have to be engineering savvy, they have to be technology savvy, just to survive in the global competitive landscape". 9

Industry reports indicate a need for developing the next generation of STEM leaders with global competence. This includes the ability to work in innovative, interdisciplinary, collaborative, and cross-cultural environments. STEM students must understand the impact of science, technology, and engineering solutions in a global and societal context. Next generation STEM leaders must be globally sophisticated and culturally aware. ${ }^{10,11,12,13}$

Recent calls to reform STEM (Science, Technology, Engineering, and Math) education, specifically engineering education, place a strong emphasis on applied math and science within the broader context of globalization, economics, the environment, and society. Popular stereotypes portray engineering as a technical, science-based, often de-contextualized activity. ${ }^{14}$ The National Academy of Engineering (NAE) report, The Engineer of 2020, echoes these concerns and calls for fundamental change in the structure, policies, and practices of engineering education. The report "urges the engineering profession to recognize what engineers can build for the future through a wide range of leadership roles in industry, government, and academia not just through technical jobs" and that "with the appropriate education and training, the engineer of the future will be called upon to become a leader not only in business but also in nonprofit and government sector." ${ }^{\prime 3}$ This paradigm shift will enable engineers to meet the demands of globalization, which requires a much broader range of skills than technical ability alone. Technology-based concerns must be balanced with more socially-oriented demands. ${ }^{14}$ Specifically, elements of good design practice include the ability to define a problem through responsible judgments based on "wide consultation, sensitivity to social, cultural and moral issues, acknowledgement of the political and economic context and critical reflection including consideration of realistic economic, environmental, social, political, ethical, health and safety, manufacturability, and sustainability constraints. ${ }^{15}$

Additionally, this 'global imperative' challenges educators to create learning environments that are relevant to a new generation of students, the millennial generation. The millennial generation is the largest and most diverse generation ever to enter college. ${ }^{16}$ These learners feel that they are "special," perhaps because they have grown up in relatively sheltered environments. ${ }^{16}$ They are team-oriented, confident, pressured, achieving, and conventional. They enjoy collaborative, cooperative, interactive, and social learning, and want educational content linked to real-life problems. ${ }^{17}$ These students engage in problem solving by integrating "sociological situations from a variety of cultures." "doing is more important that knowing."18 Jonas-Dwyer and Romano state these students are also civic-minded, and respectful, and that they "want to be the leaders", they want challenge, and they want to work with their friends. These millennial learning needs and psychological constructs necessitate providing flexible, meaningful learning environments. ${ }^{19}$

\section{BACKGROUND: THE ROLE OF GLOBALIZATION AND GLOBAL CITIZENSHIP}

Educating socially responsible global citizens integrates several concepts from current educational research efforts. These include concepts of intercultural competence, global competence, and global citizenship. Cultural and global competence includes basic attitudes, 
knowledge and skills. ${ }^{20,21}$ Requisite attitudes include: openness to others and other cultures while withholding judgment and respecting and valuing others. Attitudes of curiosity and discovery while maintaining an ability to tolerate ambiguity are also essential. Learners build on these attitudes by gaining knowledge and cultural self-awareness and then being willing to learn about the new cultural norms, customs, values, beliefs, and languages. Culturally competent individuals must be able to listen, observe, evaluate, analyze, interpret and finally relate to others in their new culture in order to become culturally and globally competent. ${ }^{20,22}$

Global citizenship a set of guiding principles that inform the way one relates experience to the wider global landscape. ${ }^{23}$ Researcher Hans Schattle imbues global citizenship with precise characteristics, identifying primary global citizenship practices as demonstrating awareness, responsibility and participation. ${ }^{24}$ Schattle suggests that awareness includes both an awareness of oneself as suggested by Deardorff, and the outside world, as well as an awareness of our interdependence and interconnectedness. The second characteristic of global citizens is taking responsibility. Those who are responsible understand that local loyalties do not justify forgetting that each human being has responsibilities to others. Finally, Schattle says that Global Citizens participate. Global citizens participate in the affairs of the community, and actually influence the people who they are exposed to by doing and saying what they know is good and right. They choose to have a voice within communities at home and abroad. ${ }^{24}$ This "expanding horizons" concept of global citizenship emphasizes increasing relationships between individuals and community. ${ }^{25}$

Within the context of STEM, global competencies must also include sensitivities to the social, cultural, and moral impacts of science, technology, and engineering-based global solutions. ${ }^{14,15}$ This reflects a shift towards a focus on social responsibility. ${ }^{26}$ Preparing next generation leaders includes integrating the concepts of globalization into undergraduate curriculum and increasing awareness and skill in global competence. ${ }^{27}$ Incorporating the concepts of global citizenship, global competence, and social responsibility into core STEM curriculum will greatly enhance the next generation of STEM learning and teaching, and the design of learning environments.

Educational research from experts in study abroad supports the importance of immersion experiences in enhancing student outcomes related to growth in intercultural awareness and sensitivity from professionals in study abroad demonstrates the many benefits this global context provides. A major multi-site study by Sutton and Rubin called the GLOSSARI Project or Georgia Learning Outcomes of Students who Study Abroad released final research outcomes in $2010 .{ }^{28}$ Investigation of STEM disciplines was not included in the study. The GLOSSARI study compared outcomes for study abroad students with outcomes for traditional non-study abroad students and documents student growth in intercultural sensitivity, cultural navigation skills, personal growth, and many other cultural skills for those who study abroad. Additionally, the study demonstrated improved graduation rates for study abroad students compared to non-study abroad students in the range of 10-30\%, depending on strata reviewed, and in particular, higher graduation rates for at-risk students. ${ }^{28}$ This extensive research effort demonstrates the importance of immersing students in a global environment if one hopes to develop and educate students for the $21^{\text {st }}$ century global workforce.

The nature of globalization requires next generation (NextGen) STEM professionals to become globally competent and socially responsible. In short, STEM students must become global citizens. However, current university education models do not provide effective tools and forums for students to think through their responsibilities as global citizens. U.S. universities 
have sought to achieve internationalization goals through many initiatives. They recruit foreign students and also send over 200,000 students to study abroad annually ${ }^{28}$ Hudzik supports the call for creating global citizens by stating "Internationalization can ultimately leverage the collective assets of the higher education sector to create a new generation of global citizens capable of advancing social and economic development for all." ${ }^{\prime 29}$ However, student exchange programs vary greatly, and the extent to which they prepare or challenge our students to collaborate with one-another and/or bring meaningful solutions to global problems may be questioned. Green challenges universities to implement global citizenship practices on a deeper level ensuring efforts are mutually beneficial and enhance the well-being of partner communities. ${ }^{30}$ Helms \& Rumbley say "Global engagement, at its essence, is about committing to meaningful relationships with partners in other parts of the world." ${ }^{31}$ While experts in international studies are slowly making progress in demonstrating the effectiveness of international studies in increasing student levels of intercultural sensitivities and awareness, research on the effectiveness of intercultural studies in attracting and retaining STEM majors is virtually nonexistent. ${ }^{28}$ Furthermore, a 2013 literature review documents that education models demonstrating effective methods for educating and retaining STEM majors by improving globally necessary workforce skills also do not exist.

The authors suggest providing learners progressive, interdisciplinary curriculum, which allows real-world problem solving in an authentic global context. They also propose using a transformative instructional approach, which model characteristics of global citizens. Transformation takes places as learners make sense of the global context, create relationships with village partners, complete meaningful projects, and ultimately return to their homes to reflect on the meaning of the experience. This is the genesis of the 360 Degree Model for Educating Socially Responsible Global Citizens (360 Global Ed model) described below.

\section{THE 360 GLOBAL ED MODEL}

The 360 Global Ed Model is an emerging education model that brings together a variety of educational concepts to form an educational approach that impacts students' knowledge, attitudes and skills, through partnerships with an international community. The model has begun to demonstrate its effectiveness for educating socially responsible global citizens.

In 2013, the authors began an interdisciplinary collaboration, and have partnered with Peacework, a non-governmental organization that connects educators and universities with village partners in areas of the world where the partnership can be mutually beneficial. A result of this initial effort was the development of the 360 Global Ed Model (see Figure 1). The intended outcome of employing this model is to develop students who are socially responsible global citizens. The authors suggest there are both internal and external outcomes that are ultimately components of the effective socially responsible global citizen. Internal components are motivations that propel a person to engage in practices of global citizenship. External components are the knowledge and skills (technical and personal) that can constantly be growing and improving, as one engages in knowing and furthering his or her involvement in the world. The transformative interdisciplinary learning environment embodies the constructivist-based theories of transformational leadership, experiential learning, and interdisciplinary teams (explained below). This learning environment has been developed within the context that NextGen students include millennial and Z generation students as they matriculate to college age. 
As noted, Schattle's model of awareness, responsibility, and participating describes the practices of global citizenship. The authors suggest the process of becoming a global citizen requires a reordering of Schattle's model to gaining awareness, participating, and taking responsibility (see Figure 2). This is operationalized through guided international service learning experiences. Awareness begins during pre-trip classroom discussions where faculty members introduce concepts of global competency and social responsibility. They provide interdisciplinary teams with a project scope, and the teams then develop, design and construct solutions for STEM-based community problems. Participation includes an immersive in-country service learning experience, authenticates and challenges student perceptions, builds on relationships to create intercultural sensitivity, and provides opportunity for personal growth, leadership and teamwork. It also reinforces discipline-specific knowledge and skills. The service learning experience includes procuring materials and equipment and constructing the project. This experience provides a rich contextual learning environment, which acts as a catalyst to help students synthesize course concepts and skills. Responsibility develops through student reflection which links experience to abstract theories and perceptions.

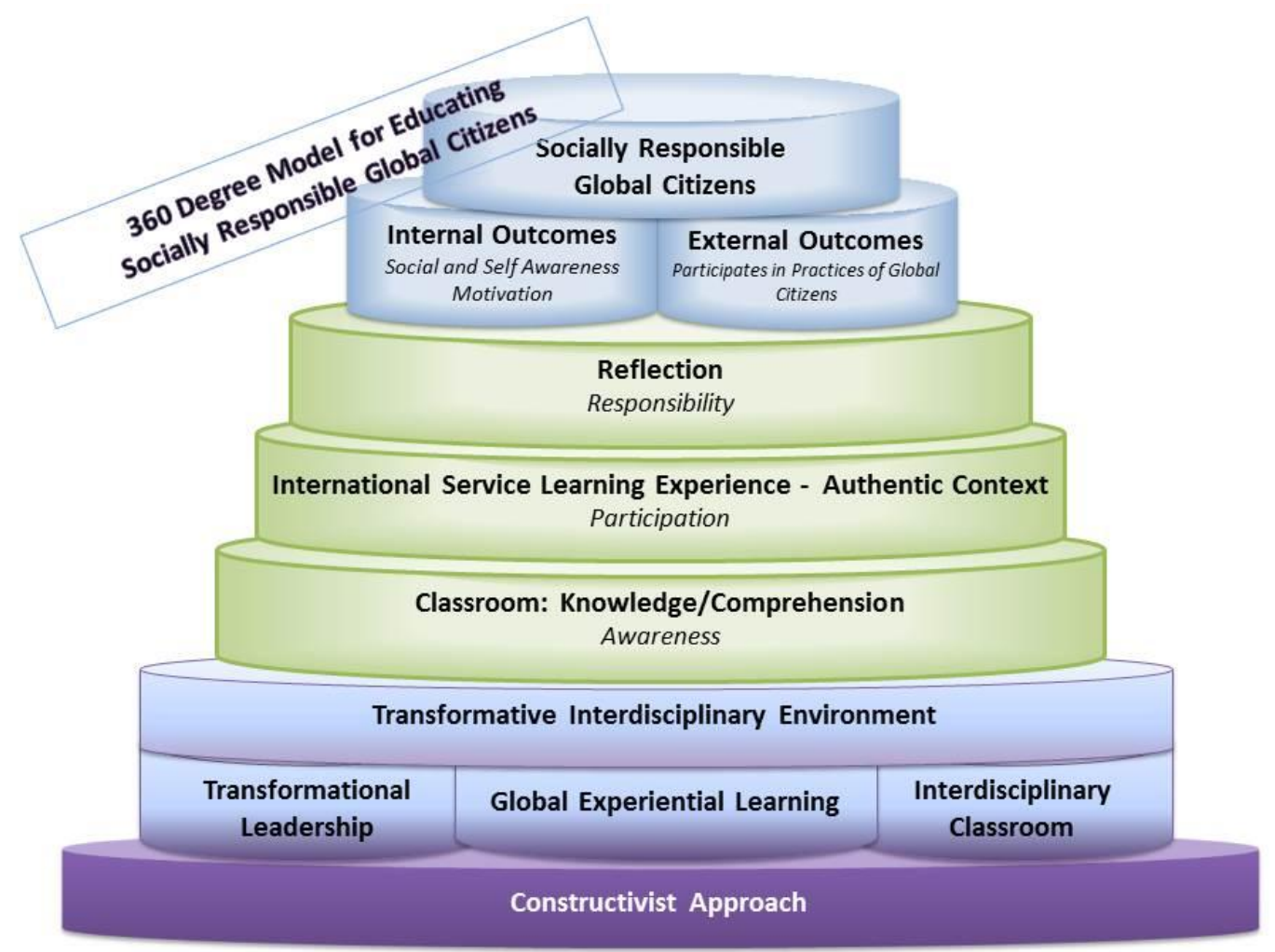

FIGURE 1

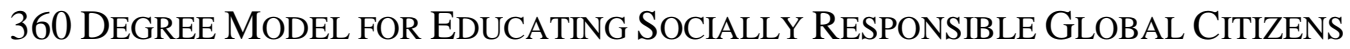




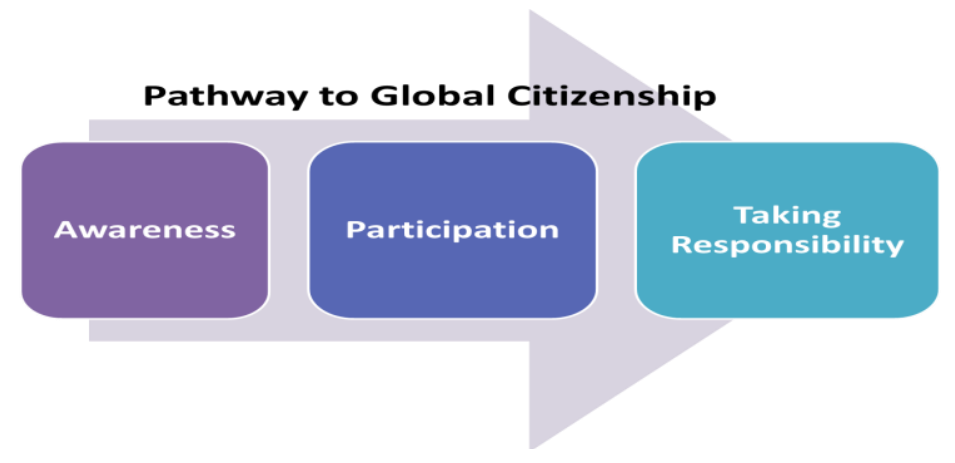

FIGURE 2

Pathway to Global Citizenship

\section{THEORETICAL UNDERPINNINGS}

Theoretical underpinnings for the 360 Global Ed Model include constructivism, interdisciplinary learning, service learning and transformational leadership. Each of these factors is a necessary component of the model, and is briefly reviewed below.

\section{Constructivism}

Constructivism is a core educational theory that is based on the premise that we construct our perspectives through our individual experiences. Incorporating previous life experiences in an educational paradigm is particularly powerful for millennial and $\mathrm{Z}$ (NextGen) generation who possess early social awareness. The ability to solve problems and take responsibility for learning ultimately resides in the learner. It is through making meaning of educational experiences that learners grow and expand their intellectual, social, and global horizons. ${ }^{12}$

\section{Interdisciplinary Learning}

Rationales for an interdisciplinary approach to education then build from this idea that learners build meaning from their experiences. When learning in an inter-professional environment, learners build cooperative, collaborative and social learning skills. They can develop interprofessional knowledge of team and leadership competencies. Conflict resolution, adaptability, flexibility, and team building through shared visions and trust building are essential competencies where learners can build skills. This inter-professional social environment then provides a safe place to understand the significance and importance of one's own professional discipline and the contribution and importance, connectedness and contributions of those from other disciplines. ${ }^{12}$ This breath and depth focus creates a T-student approach that appeals to NextGen students who process large amounts of information, develop strong specialty skills, while wanting to serve a larger social good. ${ }^{32,33}$ It is during post-trip reflection that learners have time to synthesize new understandings and experiential meanings.

\section{Service Learning}

International service learning is essential to the effectives of the 360 Global Ed Model. Service learning is grounded in experiential education theory. ${ }^{34,35,36}$ Experiential education theory's primary assumption is that experience is the foundation of learning and that service in a variety 
of forms provides authentic context experience. The benefits of service learning on student outcomes are well documented. These include positive impacts on analytical and critical thinking skills, inter-personal skills, and improved engagement in professional commitment. Developing meaningful solutions to real world problems provides an environmental and societal context for personal and professional growth. Global citizenship requires immersive, international experience. ${ }^{37,38}$ Ruddock reported that "development of cultural sensitivity" was "a circular process - of experiencing stress in a strange environment, taking on ways of [the] host culture, and comparing [the] host culture with their own" [culture]. ${ }^{22}$ These rich, contextually based global experiences followed by guided reflection provide a transformative environment for student learning. ${ }^{22,34}$ Service learning in the engineering disciplines varies tremendously on locations (domestic/international), disciplines, and project types. ${ }^{39,40,41,42,43,44,45}$

\section{Transformational Leadership}

The authors argue that an instructional paradigm based in transformational leadership is imperative in retaining STEM students. Traditional education models often feature the professor as expert, and while fulfilling this capacity may, to a large extent still be warranted, millennial students often dismiss faculty expertise as only partially relevant. In today's society where information is instantly accessible and quickly outdated students value doing more than knowing. ${ }^{18}$ Millennial students display frustration when faculty tries to leverage personal expertise. Transformational leaders, in contrast, demonstrate that there are multiple sources from which to gain expertise, and therefore stimulate and inspire students to achieve extraordinary outcomes by solving real-world problems in an authentic context. By encouraging learners to develop and create solutions to these problems, the learners must create relationships, research solutions, and develop their own leadership capacities. Transformational leaders help learners to grow and develop by responding to learners' individual needs, and by encouraging them to align their personal objectives and goals with the needs of the community, and the educational, and group goals. ${ }^{46}$ Transformational leaders maintain high performance expectations among their students. They are role models that inspire others, demonstrate consideration, promote intelligent stimulation, and foster acceptance of group goals. Callow noted that millennial learners also appreciate contingent rewards, and leaders who display self-belief and a sense of humor. ${ }^{47}$ Correlations between transformational leadership teaching behaviors and millennial student needs are well documented. ${ }^{48}$ The authors argue that an instructional paradigm based in transformational leadership is imperative in retaining STEM students.

\section{INTERNATIONAL SERVICE LEARNING EXPERIENCE THROUGH AUTHENTIC CONTEXT: VILLAGE NETWORK}

The village network model provides multi-disciplined, collaborative, international service learning experiences to students. This 'participation' toward global citizenship is bounded by awareness gained in pre-experience classroom efforts and post-experience responsibility through reflection. Courses offerings illustrating the efforts of the program include, "Global Citizenship and Social Responsibility" and "Social Responsibility in Construction Management". The inclass portion of these courses target knowledge and comprehension of social responsibility and globalization issues. From the engineering perspective, these courses focus on understanding the role of construction engineering and construction managers as socially responsible, global citizens within the context of multi-disciplined teams. Trip and project planning occurs during 
the in-class component. Multi-disciplined student teams from Health Science, Education, Engineering, and other disciplines develop integrated solutions for school or community defined needs. These solutions may include teacher training materials, educational curriculum, and the design of a related construction project. Design considerations include the use of local materials, ease of use and sustainability, as well as operations and maintenance. Student teams develop project plans that detail the materials required, quantity and cost estimates, a project schedule, a resource utilization plan and a daily safety plan. During the in-country experience, students procure materials and equipment and construct their designs. Team leadership responsibilities rotate among students. In 2008, 2012, 2013, and 2014 projects included water distribution and rainwater harvesting, trash collection receptacles, school ground paths, kinder playground, chicken coop, and a school garden. Additionally, students work closely with community leaders, teachers, and students of host country schools fostering long term global relationships. Post trip reports and reflection completes the course component of the 360 Global Ed Model.

A multi-dimensional course assessment was used to determine if the approach was successful in terms of student education and growth, industry participation and community interaction. To assess the learning objectives of the class, mixed methods were used. These include; post experience surveys, participant observation by faculty, student journals and reflective essays.

\section{Post Survey Results}

Post trip assessment results demonstrate personal growth in the areas of global citizenship and social responsibility, (table 1 below), teamwork and leadership, academic discipline and professional growth.

TABLE 1

SELF-ASSESSMENTS OF GROWTH IN GLOBAL UNDERSTANDINGS, CROSS CULTURAL ABILITIES

\begin{tabular}{|l|c|}
\hline Understanding of global issues & 5.09 \\
\hline Ability to recognize my own biases, prejudices or stereotypes & 5.32 \\
\hline Cross-cultural sensitivity & 5.18 \\
\hline Ability to interpret aspects of other cultures & 4.91 \\
\hline Ability to compare and contrast my host country with my own & 5.45 \\
\hline Ability to understand the scope and depth of the health problems in the country I visited & 4.86 \\
\hline Ability to relate to people from other cultures & 5.18 \\
\hline Ability to work with/for people from other cultures & 5.32 \\
\hline Understanding issues that affect those in the larger global community & 5.36 \\
\hline Ability to respect others in spite of cultural differences & 5.32 \\
\hline How much I care about the problems of people in other countries & 5.41 \\
\hline
\end{tabular}

Students were asked to rate their level of improvement in areas of global citizenship. A likert scale 1-6 was used with 1 being no improvement and 6 being improved greatly and zero meaning not applicable. As table 1 indicates, students felt they experienced definite improvement in areas of globalization, cultural sensitivity, and social responsibility.

In the areas of globalization, teamwork and leadership, academic discipline, and professional and personal growth, students were asked open-ended questions. Student responses are highlighted below in tables 2-5 and demonstrate positive growth in these areas. 
TABLE 2

Global CitIZENSHIP INSIGHT

\begin{tabular}{|l|l|}
\hline \multicolumn{1}{|c|}{ Qualitative Question } & \multicolumn{1}{|c|}{ Response } \\
\hline $\begin{array}{l}\text { Whave about global } \\
\text { citizenship? }\end{array}$ & $\begin{array}{l}\text { "I've learned what it means to be a global citizen. Before I could } \\
\text { maybe tell you what it vaguely sounded like global citizenship } \\
\text { should be, now I can tell you that for me, being a global citizen } \\
\text { means being there and being open to understanding another } \\
\text { culture while working with and learning from the native people to } \\
\text { improve everyone's overall well being." } \\
\text { "I learned that we are all global citizens, and that we are } \\
\text { connected through personal relationships." } \\
\text { "Global citizenship is more than knowing that I am part of a } \\
\text { larger humanity, more than giving my money, more than giving } \\
\text { my time. Being a socially responsible, global citizen means } \\
\text { listening to the perspective of the people and meeting them at } \\
\text { their level without assuming that I know better or can do anything } \\
\text { better. I am neighbors and friends to the rest of the world and it is } \\
\text { my responsibility to open my eyes and heart to that." } \\
\text { "Seeing face to face, that these are human souls that love and } \\
\text { laugh and are really no different from us, was a big wave of } \\
\text { reality really hitting me that the rest of the world is full of } \\
\text { beautiful people suffering so much, and it is our responsibility to } \\
\text { be aware of what is going on and attempt to get involved in a } \\
\text { positive way." }\end{array}$ \\
\hline
\end{tabular}

TABLE 3

TEAMWORK

\begin{tabular}{|l|l|}
\hline \multicolumn{1}{|c|}{ Qualitative Question } & \multicolumn{1}{c|}{ Response } \\
\hline $\begin{array}{l}\text { What did you learn about } \\
\text { teamwork? }\end{array}$ & $\begin{array}{l}\text { "You must utilize everyone's strengths to implement powerful } \\
\text { projects" }\end{array}$ \\
\cline { 2 - 2 } & $\begin{array}{l}\text { "I learned that working with people from other areas is extremely } \\
\text { rewarding because we all offer different perspectives on the same } \\
\text { problem and can honestly find the best possible solution" }\end{array}$ \\
\cline { 2 - 2 } & $\begin{array}{l}\text { "Teamwork is an amazing thing. If you get a group of passionate } \\
\text { people together, the possibilities are endless" }\end{array}$ \\
& "I learned more about teamwork in 1 week that I have in entire \\
semesters of lab courses."
\end{tabular}


TABLE 4

DISCIPLINE SPECIFIC EXPERIENCE

\begin{tabular}{|l|l|}
\hline \multicolumn{1}{|c|}{ Qualitative Question } & \multicolumn{1}{c|}{ Response } \\
\hline $\begin{array}{l}\text { How will this experience } \\
\text { help in your discipline? }\end{array}$ & $\begin{array}{l}\text { "It made me aware of different perspectives. Seeing a problem or } \\
\text { challenge from another's point of view is always helpful in any } \\
\text { discipline." }\end{array}$ \\
\cline { 2 - 2 } & "I now approach engineering with multiple perspectives." \\
\cline { 2 - 2 } & $\begin{array}{l}\text { "This will allow me to see things with a different perspective and } \\
\text { have an open mind to the way things could work." }\end{array}$ \\
\hline
\end{tabular}

TABLE 5

CAREER

\begin{tabular}{|l|l|}
\hline Qualitative Question & Response \\
\hline \multirow{2}{*}{$\begin{array}{l}\text { How will you use this } \\
\text { experience in your career? }\end{array}$} & $\begin{array}{l}\text { "I want to find a way to take my major to a global perspective. } \\
\text { It's inspired me to want to help and do more." }\end{array}$ \\
\cline { 2 - 2 } & "I will utilize an open mind and respect diversity." \\
\hline
\end{tabular}

TABLE 6

PERSONAL GROWTH

\begin{tabular}{|l|l|}
\hline Qualitative Question & Response \\
\hline $\begin{array}{l}\text { When you look back on your } \\
\text { study abroad experience, }\end{array}$ & "I learned that I'm more capable than I give myself credit for. \\
what did you learn about & I'm valuable in any team even if I don't have any technical \\
yourself (personal growth)? & "'That I have the ability to lead." \\
\cline { 2 - 3 } & $\begin{array}{l}\text { "I learned that I have so much to give, be it time, effort, a helping } \\
\text { hand, a listening ear. There is so much I can do to help others in } \\
\text { the world and I hope to do so throughout the rest of my life." }\end{array}$ \\
\cline { 2 - 2 } & $\begin{array}{l}\text { "I can do anything if I put my mind to it, no matter how much it } \\
\text { scares me or how long I thought it was something I'd never be } \\
\text { able to do." }\end{array}$ \\
\hline
\end{tabular}

These testimonials demonstrate the tremendously positive internal and external outcomes from the multi-disciplined collaborative service-learning experience created in the 360 Global Ed model. Cumulatively, they are testament to the necessity for providing students international service learning opportunities.

\section{Observations}

Throughout the entire experience the authors observed the behaviors of the students, how they performed as a group, how they reacted to challenges on the jobsite, how they collaborated and how they personally and academically advanced. The one thing that was constant during projects is change. Change occurred in schedules, in scope and in design. Experiencing changed conditions and the necessity for flexibility and decision-making in ambiguous circumstances is a tremendous learning point in these projects. For example, changes in client requests and needs 
can have significant impact on original plans. One particular example is when the client did not allow the student teams to work on site on Sunday. This led to the decision to not do the project and combine teams to work on another project. This led to scope and project planning changes in real time.

During the construction phase, changes to designs occurred daily based upon the challenges the teams face and the requests of the school administration. For example, fire ants, lack of wheelbarrows and the intense heat required that the teams alter their schedules and work together to accomplish their projects. An example of a critical schedule change was the presence of the over 1,000 children on the site. The solution is to reschedule the workday. To accommodate recess and lunch when students were out of class and around the work site, the schedule was adjusted. Although this resulted in longer days, it allowed the teams time to interact with children and provide for a safer jobsite.

Access to water was another challenge for project teams. The town water system may only supply water to for certain periods or amounts during the day. Teams planned their work around this access to have enough water to mix concrete for foundations and mortar for the masonry walls. An example solution was teams working together by utilizing the unused 250-liter water tanks from one project as temporary storage to supply water for concrete and mortar mixing needs for another project.

Changing student leadership each day can have significant impact on team dynamics and performance. Each student leader exhibits different leadership styles and traits. Student leaders, with appropriate mentoring and feedback, learn and improve upon their leadership approach; some gain new levels of confidence, while others excel beyond expectations.

\section{Student Reflections}

The service-learning component of the 360 Global Ed model provides a real life example of the project planning process, the challenges of working in teams, and significance of social responsibility. As noted, the students thoroughly planned their projects but during the building process conditions changed and they had to adapt. This was reflected in the students' reflections. One student wrote, "No matter how much planning, there is always more to be done than originally thought." Another student titled a section in their daily journal, "What we planned, and what really happened."

This international service-learning program is far greater than just the experience of traveling to another country. Students who participated in previous study abroad trips noted that they felt like a foreigner in other countries; however, in Belize, they were part of the community. One student noted, "We were not visitors, we were accepted into the community, we were part of the culture." Another student wrote, "Leaving the Belizean [school] boys behind at the worksite was sadder than I thought it would be. Some of those boys annoyed me all week, but when our bus pulled out of the gravel lot, I was sad to leave them." Students grew to understand that they are part of a global community and that they can and should make a difference. One student said, "I learned that socially responsibility means that those of us that are fortunate should volunteer our time and resources to help those less fortunate". Another student noted ".... working with children can also be heartbreaking, just to see how little they have and how upset one girl was when she dropped her pencil through the floorboard of the school".

\section{Unintended impacts}

At the end of one trip, the students realized the impact their actions had on the community and the improvement of the quality of life for all who attend and work at the primary school. The 
tangible impacts of the projects constructed are not the only contribution the students made to the community. The vice principal, with tears of joy in her eyes, thanked the group and stated, "Your efforts have inspired us to begin a program to plant flowers in the bed areas created by the paths." She also took special care to recognize the hard work of the women in the group, "Women in our culture do not do things like manual labor, you have inspired us." These gender roles were noted in the journal of every female student.

\section{CONCLUSION}

Educating the next generation of engineering professionals requires providing a broad perspective in the areas of social responsibility and global citizenship. The 360 Global Ed model provides a theoretically supported transformative framework of awareness, participation, and responsibility to provide rich internal and external outcomes toward social responsibility and global citizenship. The multi-disciplined, collaborative nature of international service-learning projects provides an authentic experience in the context of a developing country. The learning that occurs during the projects is hands-on and experiential. The mentoring of students is accomplished through industry guidance and peer-to-peer interaction, creating a community of practice. The pre-trip classroom work serves to prepare the students for the experiences they would have on-site and enabled them to work collaboratively. Assessing students through a variety of observational methods, journals, and reflective essays provides insight into how transformational international service-learning trips are for college students. Based upon the success of this project and the lessons learned, the authors are confident that the $360 \mathrm{Global} \mathrm{Ed}$ model provides a framework for successful implementation of international service learning courses in other university programs.

\section{REFERENCES}

\footnotetext{
${ }^{1}$ Council on Competitiveness, Innovate America: Thriving in a world of challenge and change. The National Innovation Initiative, Washington, DC: Council on Competitiveness, 2005. Retrieved from: http://www.compete.org/nii/

${ }^{2}$ Freeman, R.B., Does Globalization of the Scientific/Engineering workforce threaten U.S. economic leadership? Innovation Policy and the Economy, Cambridge: MIT Press, 2006.

${ }^{3}$ OSTP (Office of Science and Technology Policy). The American Competitiveness Initiative. Washington, DC: U.S. Office of Science and Technology Policy, 2006. Retrieved from: http://www.ostp.gov/ACI-Booklet.pdf.

${ }^{4}$ Partnership 21. Learning for the 21st Century: A Report and MILE guide for $21{ }^{\text {st }}$ Century Skills, Partnership for the $21^{\text {st }}$ Century, 2012. Retrieved from: http://www.p21.org/storage/documents/P21_Report.pdf.

${ }^{5}$ Pelligrino, J.W., Hilton, M., Education for Life and Work: Developing Transferable Knowledge and Skills in the 21st Century, National Research Council, National Academies Press, 2012.

${ }^{6}$ United Nations (U.N.). Resolution of the General Assembly of the United Nations, New York, 8 September 2000.

Retrieved from: www.un.org/millenniumgoals.

${ }^{7}$ Business Roundtable. AMERICA 21: A New Approach To The 21st Century Workforce, 2008. Retrieved from: http://businessroundtable.org/studies-and-reports/america-21.

8 Sununu, J.E., Cardona, M., STEM fund key to US global competitiveness, 2010. Retrieved from: http://thehill.com/blogs/congress-blog/education/305061-stem-fund-key-to-us-globalcompetitiveness\#ixzz2Y2NNBmko.

${ }^{9}$ Suresh, S., National Convocation Highlights Best Practices for Improving Stem Education, 2011. Retrieved from:
} 
http://www.nsf.gov/news/news_summ.jsp?cntn_id=121796.

10 ABET, Inc., Criteria for accrediting engineering programs. ABET Engineering Accrediting Commission, 20102011. Retrieved from: http://www.abet.org/uploadedFiles/Accreditation/Accreditation_Process/Accreditation_Documents/Archive/criteriaeac-2010-2011.pdf.

11 Dunderstatt, J., Engineering for a Changing World: The Millennium Project, University of Michigan, 2008.

${ }^{12}$ Harvan, R. A., Jensen, G. M., \& Royeen, C. B., Leadership in Interprofessional health education. Sudbury: Jones and Bartlett Publishers, 2009.

13 NAE, The Engineer of 2020: Visions of Engineering in the New Century. Washington, D.C.: The National Academies Press, 2004.

${ }^{14}$ Kuhn, S., When Worlds Collide: Engineering Students Encounter Social Aspects of Production. Science and Engineering Ethics, 4(4), 457-472, 1998.

15 Conway, R., Ethical judgements in genetic engineering: The implications for technology education. International Journal of Technology and Design Education, 10(3), 239-254, 2000.

${ }^{16}$ Strauss, W., \& Howe, N., Generations: A History of America's Future, 1584 to 2069. New York: Marrow, 1991.

17 Monaco, M., \& Martin, M., The Millennial Student: A New Generation of Learners. Athletic Training Education Journal. 2 (Apr-Jun):42-46, 2007.

18 Northern Illinois University (NIU), Millennial's: Our newest generation in higher-education, Faculty Development and Instructional Design Center, 2011, Retrieved from: http://www.niu.edu/facdev/resources/guide/students/millennials_our_newest_generation_in_higher_education.pdf.

19 Jonas-Dwyer, D. \& Pospisil, R, "The millennial effect: Implications for academic development." Proceedings of the 2004 annual international conference of the Higher Education Research and Development Society of Australasia (HERDSA), 2004.

${ }^{20}$ Deardorff, D. K., Identification and assessment of intercultural competence as a student outcome of internationalization. Journal of Studies in International Education, 10(3), 241-266, 2006.

${ }^{21}$ Hunter, W., Knowledge, skills, attitudes, and experiences necessary to become globally competent. (Doctoral dissertation, Lehigh University). 2004, Retrieved from: http://www.globalcompetence.org/research/WDHdissertation-2004.pdf.

${ }^{22}$ Ruddock, H.C. \& De, S.T., Developing cultural sensitivity: Nursing student's experiences of a study abroad programme. Journal of Advanced Nursing. 59(4), 361-369, 2007.

23 Oxfam, Education for Global Citizenship: A guide for schools, 2006, Retrieved from: http://www.oxfam.org.uk/education/gc/files/education_for_global_citizenship_a_guide_for_schools.pdf.

24 Schattle, H., The practices of global citizenship. Lanham: Rowman \& Littlefield Publishers Inc., 2008.

25 Richardson, G.H., Conflicting imaginaries: Global citizenship education in Canada as a site of contestation In M.A. Peters, A. Britton, \& H. Blee (Eds.), Global citizenship education: philosophy, theory, and pedagogy (pp. 327). Rotterdam: Sense Publishers, 2008.

26 Davies, L., Global Citizenship; abstraction or framework for action? Educational Review, 58(1), 5-25, 2006.

27 Mbugua, T., Fostering culturally relevant/responsive pedagogy and global awareness through the integration of international service-learning in courses. Journal of Pedagogy, 1(2), 87-98, 2010.

28 Sutton, R.C, \& Rubin, D.L., Documenting the Academic Impact of Study Abroad: Final Report of the GLOSSARI Project, 2010.

${ }^{29}$ Hudzik, J., Executive summary: Comprehensive internationalization from concept to action Executive summary: Comprehensive internationalization from concept to action, 2011, Retrieved from: http://www.nafsa.org/_/File/_/cizn2011_execsummary.pdf.

${ }^{30}$ Green, M., Acting as global citizens: A challenge to U.S. colleges and universities, 2013, Retrieved from: http://www.nafsa.org/Explore_International_Education/Trends/TI/Acting_as_Global_Citizens_A_Challenge_to_U S___Colleges_and_Universities/.

${ }^{1} 1$ Helms, M., \& Rumbley, L., A primer for global engagement. International Briefs for Higher Education Leaders, 2012 Retrieved from: http://www.acenet.edu/news-room/Documents/International-Briefs-2012-November-GlobalEngagement.pdf. 
32 Berland, M., "What America Cares About: Compassion Counts More Than Ever." Parade. (March 27, 2010)http://www.parade.com/news/what-america-cares-about/featured/100307-compassion-counts-more-thanever.htm

33 Posnick-Goodwin, S., "The Most Technologically Advanced yet." California Teachers Association. (June 22, 2011) http://www.cta.org/Professional-Development/Publications/Educator-Feb-10/Most-technologically-advancedgeneration.aspx

34 Dewey, J., Experience and Education, New York, NY, Kappa Delta Pi, 1938.

${ }^{35}$ Piaget, J., The Origins of Intelligence in Children, New York, NY, International University Press, 1952.

${ }^{36}$ Kolb,D., Experiential Learning: Experience as the source of learning and development, Englewood Cliffs, N.J., Prentice Hall, 1984.

${ }^{37}$ Astin, A.W., Vogelgesan, L.J., Ikeda, E.K., \& Yee, J.A., How Service Learning Affects Students, Higher Education Research Institute, University of California, Los Angeles, 2000.

${ }^{38}$ Eyler, J., \& Giles, D.E., Where's the Learning in Service-Learning? San Francisco, CA: Jossey-Bass Publishers, 1999.

${ }^{39}$ Borg, J.P., \& Zitomer, D.H., Dual-team model for international service learning in engineering; Remote solar water pumping in Guatemala. Journal of Professional Issues in Engineering Education and Practice, 134(2), 178$185,2008$.

${ }^{40}$ Feisman, A., Wittig, J., Milnes, J., Baxter, A., Moreau, J., \& Mehta, K., Validation process of a social entrepreneurial telemedicine venture in East Africa. International Journal for Service Learning in Engineering, 5(1), $1-24,2010$.

${ }^{41}$ Gonzalez, E.C., Heisman, E.A., \& Lucko, G., Student-centered learning environment for disaster mitigating engineering design and deployment in developing regions. International Journal for Service Learning in Engineering, 5(1), 189-209, 2010.

${ }^{42}$ Padmanabham, G., \& Katti, D., Using community-based projects in civil engineering capstone courses. Journal of Professional Issues in Engineering Education and Practice, 128 (1), 12-18, 2002.

${ }^{43}$ Savage, R., Chen, K.C., \& Vanasupa, L., Integrating project-based learning throughout the undergraduate engineering curriculum. Journal of STEM Education, 8(3), 15-17, 2007.

${ }^{44}$ Sevier, C., Chyung, S.Y., Schrader, C., \& Callahan, J., What value does service learning have on introductory engineering students' motivation and ABET program outcomes?, Journal of STEM Education, 13(4) 55-70, 2012.

${ }^{45}$ Wigal, C.M., McMahon, E., \& Littleton, M., Measuring the benefit of service oriented student design projects, Proceedings of the $38^{\text {th }}$ ASEE/IEEE Frontiers in Education Conference, Saratoga Springs, NY., 2008.

${ }^{46}$ Bass, B. M., Transformational leadership: Industrial, military, and educational impact. Mahwah, NJ: Erlbaum, 1998.

${ }^{47}$ Callow, N., Transformational Leadership in Higher Education. Retrieved from: http://www.heacademy.ac.uk/assets/hlst/documents/resource_guides/transformational-leadership.pdf, 2011.

48 Mawn, L. Callow, N., Hardy, J., \& Arthur, C., Development and Assessment of a Transformational Leadership Inventory in Higher Education Final Report. Retrieved from:

http://www.jisctechdis.ac.uk/assets/hlst/documents/projects/round_11/r11_callow_final.pdf., 2011. 